\title{
18. AGE AND NATURE OF BASALTS FROM THE TYRRHENIAN ABYSSAL PLAIN
}

\author{
F. Barberi, ${ }^{1}$ H. Bizouard, ${ }^{2}$ G. Capaldi, ${ }^{3}$ G. Ferrara, ${ }^{4}$ P. Gasparini, ${ }^{3}$ F. Innocenti, ${ }^{1}$ J.L. Joron, ${ }^{5}$ B. Lambret, ${ }^{5}$ M. \\ Treuil, ${ }^{5}$ and C. Allègre 5
}

\begin{abstract}
Geochemical and petrological analyses of samples cored in the basement of the Tyrrhenian Abyssal Plain demonstrate that this basin is floored by a sequence of at least 250 meters of basalts with a clear oceanic tholeiitic affinity. The oldest recovered basalts have a $\mathrm{K}-\mathrm{Ar}$ age of $7.3 \pm 1.3 \mathrm{~m} . \mathrm{y}$. These data strongly favor the hypothesis of an origin by back-arc spreading for the Tyrrhenian Abyssal Plain and imply that the formation of oceanic crust was already active in pre-Messinian times.
\end{abstract}

\section{INTRODUCTION}

The objective of our work was to obtain chemical data on age-dated samples so that their petrochemical affinity could be established to contribute to the debate on the origin of the Tyrrhenian Basin. Two main hypotheses have been proposed. It is considered as either a marginal back-arc basin related to lithospheric subduction at a plate margin near the Ionian side of Calabria (Boccaletti and Guazzone, 1972; Barberi et al., 1973), or a basin created in the late Tertiary by rapid foundering of continental crust (Van Bemmelen, 1969; Heezen et al., 1971; Selli and Fabbri, 1971). Eighteen samples of igneous rocks from Cores 2, 7, 12, and the outer barrel of Hole 373A have been obtained. All samples are affected to varying degrees by alteration; furthermore, most samples of volcanic breccias were difficult to analyze because of the scarcity of homogeneous rock fragments. Analytical work has therefore been concentrated on the following lessaltered samples selected on the basis of thin-section study: Sample 2-1, 136-142 cm; Sample 4-1, 87.5-92 $\mathrm{cm}$; Samples 7-2, 94-100 cm, 7-3, 100-105 cm; 7-4, 130-135 cm; and samples from Core 12 and outer barrel (OB). Except the sample from Core 2, all of these samples have also been dated by the $\mathrm{K} / \mathrm{Ar}$ method.

\footnotetext{
${ }^{1}$ Istituto di Mineralogia e Petrografia dell 'Università -Centro di Geologia Strutturale e Dinamica dell'Appennino, Pisa (Italy).

${ }^{2}$ Laboratoire de Pétrographie et Volcanologie-Université de Paris XI, Orsay (France).

${ }^{3}$ Osservatorio Vesuviano-Istituto de Geologia e Geofisica delI'Università di Napoli, Napoli (Italy).

${ }^{4}$ Laboratorio di Geocronologia e Geochimica Isotopica del C.N.R., Pisa (Italy).

5 Laboratoire de Géochimie-Institut de Physique du Globe de Paris-Groupe des Sciences de la Terre, Laboratoire Pierre Süe, Gif sur Yvette (France).
}

\section{PETROGRAPHY}

All samples except Sample 7-4 130-135 cm, and the sample from Core 12 are porphyritic, having large plagioclase phenocrysts (more than $2.0 \mathrm{~mm}$ in length, maximum length $4.8 \mathrm{~mm}$ ). Plagioclase occurs also in abundant microphenocrysts $(0.8 \mathrm{~mm})$ which display a gradual size variation. In Sample 7-2, 94-100 cm, plagioclase glomeroporphyritic clots are observed. Clinopyroxene is confined to the groundmass, where it generally forms intergranular crystals among the plagioclase microlitic laths. Olivine is rare to absent; only in Sample 7-2, 94-100 cm are larger crystals, with a mean size of $0.3 \mathrm{~mm}$, observed; they are completely converted into iddingsitic products. In thin section of the same sample a large phenocryst (up $1.45 \mathrm{~mm}$ in length) of a mafic crystal (olivine?) is completely transformed to iron oxides. Clinopyroxene and plagioclase (sometimes with iron oxides) form intergrowths in the groundmass of some samples (Samples 4-3, 130$139 \mathrm{~cm}, 7-4,130-135 \mathrm{~cm})$. In Core 4 a tendency toward variolitic texture is observed. The groundmass is dotted with opaque minerals. The original glassy matrix is totally transformed to brown-to-greenish clay minerals associated with a more or less pronounced geothitic pigmentation. Among the clay minerals small laths of a well-crystallized phase with yellow-green to olive-green pleochroism (nantronite?) is randomly distributed. Alteration products may fill small fractures within the plagioclase phenocrysts whose core may also be partly transformed to carbonate (Sample 7-4, 130$135 \mathrm{~cm})$. Calcite filling veins and vesicles are frequently observed. Vesicles are also filled with zeolite in places (Sample 4-3, 135-139 cm).

Microprobe analyses have been carried out on plagioclase and clinopyroxene of outer barrel samples (Table 1). Plagioclase changes gradually in composition from An85 to An54; a discontinuity is observed between the microlite rim and crystallites, with the 
TABLE 1

Microprobe Analyses of Plagioclase and Clinopyroxene of Sample From Outer Barrel

\begin{tabular}{|c|c|c|c|c|c|c|c|c|}
\hline & \multicolumn{4}{|c|}{ Plagioclase } & \multicolumn{4}{|c|}{ Clinopyroxene } \\
\hline & $\begin{array}{l}\text { Pheno- } \\
\text { cryst } \\
\text { Core }\end{array}$ & $\begin{array}{c}\text { Large } \\
\text { Micro- } \\
\text { lite }\end{array}$ & Microlite & $\begin{array}{l}\text { Microlite } \\
\text { Rim and } \\
\text { Cristallite }\end{array}$ & $\begin{array}{l}\text { Grain } \\
\text { Core }\end{array}$ & $\begin{array}{l}\text { Inter- } \\
\text { mediate } \\
\text { Zone }\end{array}$ & Microlite & $\begin{array}{l}\text { Cris- } \\
\text { tallite }\end{array}$ \\
\hline $\mathrm{SiO}_{2}$ & 46.9 & 50.8 & 54.4 & 65.6 & 49.6 & 49.2 & 49.0 & 50.0 \\
\hline $\mathrm{TiO}_{2}^{2}$ & - & - & - & - & 1.50 & 1.79 & 1.91 & 1.21 \\
\hline $\mathrm{Al}_{2} \mathrm{O}_{3}$ & 33.5 & 31.0 & 28.4 & 20.5 & 4.32 & 3.93 & 3.53 & 1.36 \\
\hline $\mathrm{FeO}^{\circ}$ & 0.54 & 0.42 & 0.65 & 0.42 & 7.22 & 9.5 & 10.4 & 14.9 \\
\hline $\mathrm{MnO}$ & - & - & - & - & 0.24 & 0.26 & 0.23 & 0.58 \\
\hline $\mathrm{MgO}$ & - & - & - & - & 15.1 & 14.4 & 13.1 & 12.0 \\
\hline $\mathrm{CaO}$ & 17.0 & 14.7 & 11.2 & 1.38 & 21.2 & 20.5 & 21.3 & 19.1 \\
\hline $\mathrm{Na}_{2} \mathrm{O}$ & 1.69 & 3.37 & 5.31 & 10.44 & 0.40 & 0.38 & 0.49 & 0.42 \\
\hline $\mathrm{K}_{2} \mathrm{O}$ & 0.03 & 0.05 & 0.08 & 0.97 & - & - & - & - \\
\hline \multicolumn{2}{|c|}{ Totals 99.66} & 100.34 & 100.04 & 99.31 & 99.58 & 99.96 & 99.96 & 99.57 \\
\hline $\mathrm{Ab}$ & 15.2 & 29.2 & 45.8 & $88.2 \mathrm{En}$ & 43.5 & 42.8 & 38.2 & 35.1 \\
\hline Or & 0.1 & 0.3 & 0.5 & $5.4 \mathrm{Fs}$ & 11.9 & 15.4 & 17.1 & 24.5 \\
\hline An & 84.7 & 70.5 & 53.7 & 6.4 Wo & 44.6 & 41.8 & 44.8 & 40.4 \\
\hline
\end{tabular}

appearance of an alkali phase (albite). $\mathrm{K}_{2} \mathrm{O}$ content is very low in all feldspar phases including the alkalic ones. Clinopyroxene is calcic and displays a more limited range of variation (Fs 12-24). Although the calcic nature of the clinopyroxene is maintained along the whole crystallization range, a slight decrease of Wo is observed with increasing Fs content. A comparison with mineralogy of basalts from various tectonic settings will be made when a more complete set of data becomes available.

\section{GEOCHRONOLOGY AND MAJOR AND TRACE ELEMENTS}

Analytical results are reported in Tables 2, 3, and 4. Major elements were obtained by wet chemical analyses (method described by Cioni et al., 1971); trace elements were obtained by neutron activation analyses (method described by Treuil et al., 1973; Chaya et al., 1973). Th and $U$ isotopic analyses were made by isotope dilution $\alpha$ spectrometry (method described in Capaldi et al., 1976).

TABLE 2

K/Ar Results

\begin{tabular}{lcrcc}
\hline $\begin{array}{c}\text { Sample (In- } \\
\text { terval in cm) }\end{array}$ & $\begin{array}{c}\mathrm{K} \\
(\%)\end{array}$ & $\begin{array}{c}\mathrm{rd}^{40} \mathrm{Ar} \\
(\%)\end{array}$ & $\begin{array}{c}\text { STP rd } \\
\text { gr K } \\
(\mathrm{cc})\end{array}$ & $\begin{array}{c}\text { AGE } \\
(\mathrm{m} . \mathrm{y} .)\end{array}$ \\
\hline $12-1,120-124$ & 0.24 & 8.0 & $2.69 \times 10^{-5}$ & $6.8 \pm 1.2$ \\
Outer Barrel & 0.27 & 13.0 & $2.49 \times 10^{-5}$ & $6.3 \pm 0.2$ \\
12 & 0.25 & 9.0 & $3.01 \times 10^{-5}$ & $7.5 \pm 1.3$ \\
$7-2,94-100$ & 0.23 & 8.0 & $2.24 \times 10^{-5}$ & $5.6 \pm 1.0$ \\
$7-3,100-105$ & 0.26 & 6.5 & $1.45 \times 10^{-5}$ & $3.6 \pm 0.6$ \\
$7-4,130-135$ & 0.16 & 4.0 & $1.84 \times 10^{-5}$ & $4.6 \pm 0.9$ \\
$4-1,87.5-92$ & 0.20 & 5.0 & $1.40 \times 10^{-5}$ & $3.5 \pm 0.7$ \\
\hline
\end{tabular}

Note: Ar measurements have been performed with a Reynolds-type mass spectrometer, statistically operated. $\lambda_{\epsilon}=0.585 \times 10^{-10} \mathrm{yr}^{-1} ; \lambda_{\beta}=4.72 \times 10^{-10} \mathrm{yr}^{-1}$; $40 \mathrm{~K} / \mathrm{K}_{\text {tot }}=1.10 \times 10^{-4}$. Error on ages based on radiogenic $40 \mathrm{Ar}$ content. For radiogenic $40 \mathrm{Ar}$ contents lower than $10 \%$ an error of $20 \%$ at $1 \sigma$ level is estimated. $\mathrm{K}$ determinations are by A.A method in duplicates with a $5 \%$ error.
TABLE 3

Major Elements and CIPW Norms

\begin{tabular}{|c|c|c|c|c|c|c|c|}
\hline & \multicolumn{7}{|c|}{ Samples (Interval in $\mathrm{cm}$ ) } \\
\hline & $\begin{array}{c}21, \\
136-142\end{array}$ & $\begin{array}{c}4-1, \\
87.5-92\end{array}$ & $\begin{array}{c}7-2 \\
94-100\end{array}$ & $\begin{array}{c}7-3 \\
100-105\end{array}$ & $\begin{array}{c}7-4 \\
130-135\end{array}$ & $\begin{array}{c}12-1, \\
120-124\end{array}$ & $\begin{array}{l}\text { Outer } \\
\text { Barrel }\end{array}$ \\
\hline $\mathrm{SiO}_{2}$ & 50.72 & 49.35 & 49.18 & 47.76 & 44.31 & 50.29 & 50.27 \\
\hline $\mathrm{TiO}_{2}^{2}$ & 1.44 & 1.18 & 0.85 & 0.88 & 0.91 & 1.43 & 1.42 \\
\hline $\mathrm{Al}_{2} \overline{\mathrm{O}}_{3}$ & 16.02 & 15.68 & 19.02 & 18.48 & 16.49 & 16.50 & 16.61 \\
\hline $\mathrm{Fe}_{2} \mathrm{O}_{3}$ & 3.50 & 4.80 & 2.32 & 4.81 & 4.79 & 2.76 & 2.52 \\
\hline $\mathrm{FeO}$ & 5.48 & 3.71 & 4.05 & 2.98 & 3.06 & 6.19 & 6.31 \\
\hline $\mathrm{MnO}$ & 0.11 & 0.12 & 0.09 & 0.11 & 0.13 & 0.12 & 0.12 \\
\hline $\mathrm{MgO}$ & 8.35 & 7.39 & 7.69 & 8.20 & 10.64 & 7.95 & 7.96 \\
\hline $\mathrm{CaO}$ & 6.46 & 11.17 & 10.31 & 10.02 & 10.64 & 7.22 & 7.06 \\
\hline $\mathrm{Na}_{2} \mathrm{O}$ & 4.10 & 3.48 & 2.99 & 2.82 & 2.37 & 4.02 & 4.05 \\
\hline $\mathrm{K}_{2} \mathrm{O}$ & 0.30 & 0.25 & 0.24 & 0.27 & 0.21 & 0.32 & 0.32 \\
\hline $\mathrm{P}_{2} \mathrm{O}_{5}$ & 0.18 & 0.15 & 0.11 & 0.10 & 0.10 & 0.17 & 0.17 \\
\hline L.o.i. & 3.09 & 2.67 & 2.93 & 3.41 & 6.19 & 2.78 & 2.89 \\
\hline Total & 99.75 & 99.95 & 99.78 & 99.84 & 99.84 & 99.76 & 99.70 \\
\hline D.I. & 36.45 & 30.91 & 26.71 & 25.45 & 20.62 & 35.89 & 36.14 \\
\hline Q & - & - & - & - & - & - & \\
\hline or & 1.77 & 1.48 & 1.42 & 1.60 & 1.24 & 1.89 & 1.89 \\
\hline$a b$ & 34.68 & 29.43 & 25.29 & 23.85 & 18.59 & 34.00 & 34.25 \\
\hline an & 24.43 & 26.43 & 37.77 & 36.97 & 33.74 & 26.04 & 26.20 \\
\hline ne & - & - & - & - & 0.79 & - & - \\
\hline di & 5.21 & 22.67 & 10.13 & 9.72 & 14.72 & 7.02 & \\
\hline hy & 16.73 & 0.22 & 11.75 & 8.72 & - & 12.48 & 12.73 \\
\hline ol & 8.23 & 11.95 & 6.37 & 11.16 & 20.11 & 10.14 & 9.86 \\
\hline $\mathrm{mt}$ & 2.17 & 2.17 & 2.17 & 2.17 & 2.17 & 2.17 & 2.17 \\
\hline il & 2.74 & 2.24 & 1.61 & 1.67 & 1.73 & 2.72 & 2.70 \\
\hline ap & 0.43 & 0.37 & 0.26 & 0.24 & 0.24 & 0.40 & 0.40 \\
\hline
\end{tabular}

Note: Norms have been calculated assuming $\mathrm{Fe}_{2} \mathrm{O}_{3}$ contents of $1.5 \%$

\section{AGE}

Individual $\mathrm{K} / \mathrm{Ar}$ dates range from $7.5( \pm 1.3)$ to 3.5 $( \pm 0.7)$ m.y. Results must however be treated with caution because of the uncertainty due to possible combined effects of Ar excess commonly observed in deep-sea basalts (see Funkhouser et al., 1968) and of the modification of K/Ar ratio by alteration of the glassy matrix of the samples. An indication of the reliability of $\mathrm{K} / \mathrm{Ar}$ dates can be obtained with the help of a ${ }^{40} \mathrm{Ar} / 36 \mathrm{Ar}$ versus ${ }^{40} \mathrm{~K} / 36 \mathrm{Ar}$ diagram (McDougall et al., 1969; Hayatsu and Carmichael, 1970).

In such a diagram (Figure 1) all samples except Sample $\mathrm{C}$ on the figure are aligned along two straight lines giving ages of $6.5( \pm 0.4)$ and $4.1( \pm 0.5)$ m.y. whose intercept gives an initial ${ }^{40} \mathrm{Ar} /{ }^{36} \mathrm{Ar}$ ratio indistin- 
TABLE 4

Trace Elements (p.p.m.) and Sr Isotopic Data

\begin{tabular}{lccccccc}
\hline & \multicolumn{7}{c}{ Sample (Interval in cm) } \\
\cline { 2 - 8 } & $2-1$, & $4-1$, & $7-2$, & $7-3$, & $7-4$, & $12-1$, & Outer \\
& $136-142$ & $87.5-92$ & $94-100$ & $100-105$ & $130-135$ & $120-124$ & Barrel \\
\hline $\mathrm{Rb}$ & 3.0 & 3.0 & 3.0 & 5.0 & 3.0 & 3.0 & 4.0 \\
$\mathrm{Cs}$ & 0.04 & 0.41 & 0.05 & 0.17 & 0.13 & 0.04 & 0.04 \\
$\mathrm{Sr}$ & 189.0 & 213.0 & 255.0 & 235.0 & 237.0 & 202.0 & 221.0 \\
$\mathrm{Ba}$ & 65.0 & 57.0 & 74.0 & 61.0 & 62.0 & 66.0 & 57.0 \\
$\mathrm{Cr}$ & 124.0 & 151.0 & 213.0 & 213.0 & 182.0 & 125.0 & 131.0 \\
$\mathrm{Co}$ & 35.5 & 35.5 & 40.6 & 33.0 & 38.6 & 33.8 & 32.2 \\
$\mathrm{Ni}$ & 49.0 & 47.0 & 114.0 & 83.0 & 86.0 & 53.0 & 54.0 \\
$\mathrm{Sc}$ & 29.0 & 35.5 & 23.7 & 25.3 & 28.3 & 28.3 & 29.3 \\
$\mathrm{Sb}$ & 0.03 & 0.28 & 0.02 & 0.05 & 0.08 & 0.04 & 0.03 \\
$\mathrm{La}$ & 8.0 & 5.4 & 5.5 & 4.5 & 4.5 & 7.3 & 7.5 \\
$\mathrm{Ce}$ & 18.8 & 13.1 & 12.8 & 10.3 & 10.3 & 16.5 & 18.1 \\
$\mathrm{Nd}$ & 11.5 & 9.2 & 8.1 & 7.2 & 7.3 & 12.0 & 9.6 \\
$\mathrm{Sm}$ & 3.6 & 2.54 & 2.4 & 2.03 & 2.13 & 3.15 & 3.5 \\
$\mathrm{Eu}$ & 1.26 & 1.07 & 0.93 & 0.84 & 0.84 & 1.22 & 1.25 \\
$\mathrm{Gd}$ & 4.1 & 3.0 & 2.9 & 2.5 & 2.6 & 4.0 & 4.0 \\
$\mathrm{~Tb}$ & 0.75 & 0.58 & 0.52 & 0.45 & 0.47 & 0.7 & 0.74 \\
$\mathrm{Tm}$ & 0.49 & 0.40 & 0.35 & 0.31 & 0.35 & 0.5 & 0.50 \\
$\mathrm{Yb}$ & 2.75 & 2.34 & 1.94 & 1.74 & 1.91 & 2.75 & 2.86 \\
$\mathrm{Lu}$ & 0.54 & 0.45 & 0.38 & 0.34 & 0.38 & 0.54 & 0.56 \\
$\mathrm{Ta}$ & 0.46 & 0.27 & 0.23 & 0.18 & 0.17 & 0.42 & 0.45 \\
$\mathrm{Zr}$ & 112.0 & 75.0 & 86.0 & 60.0 & 45.0 & 112.0 & 123.0 \\
$\mathrm{Hf}$ & 3.1 & 2.1 & 1.9 & 1.6 & 1.7 & 2.94 & 3.1 \\
$\mathrm{Th}$ & 0.78 & 0.45 & 0.61 & 0.58 & 0.49 & 0.78 & 0.79 \\
$\mathrm{U}$ & 0.24 & 0.13 & 0.20 & 0.19 & 0.17 & 0.29 & 0.32 \\
$87 \mathrm{Sr} / 86 \mathrm{Sr}$ & 0.70292 & 0.70299 & 0.70300 & 0.70306 & 0.7032 & 0.7031 & $(1) 0.70291$ \\
& \pm 0.00009 & \pm 0.00013 & \pm 0.00009 & \pm 0.00007 & \pm 0.0001 & \pm 0.0001 & \pm 0.00009 \\
& & & & & & & $(2) 0.7031$ \\
& & & & & & & \pm 0.0001 \\
\hline & & & & & & &
\end{tabular}

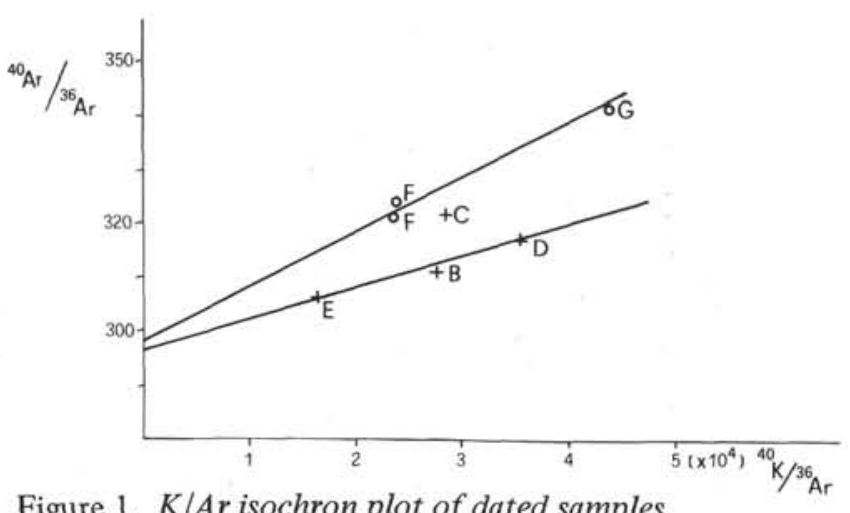

Figure 1. K/Ar isochron plot of dated samples.

guishable from the atmospheric ratio (295.5). This latter fact indicates that significant initial ${ }^{40} \mathrm{Ar} \mathrm{rad}$ excess was not present in the sample and that no significant post-eruptive alteration of $\mathrm{K} / \mathrm{Ar}$ ratio has occurred. The date measured in Sample $\mathrm{C}$ is, however, stratigraphically inconsistent. We consider that this is the only "age" to be rejected.

The youngest $\mathrm{K} / \mathrm{Ar}$ dates indicate an upper lower Pliocene age. The dated lava pile cored in Hole 373A covers a range of ages of about $4 \mathrm{~m}$.y. (from Messinian to upper lower Pliocene) with a total thickness of about 170 meters. This suggests a low rate (less than $40 \mathrm{~mm} / 10^{3}$ years) of basaltic crust formation in the Tyrrhenian Abyssal Plain. The rate of basalt outpouring must obviously have been much higher in the big seamounts of the Abyssal Plain (Magnaghi, Vavilov, Marsili). Radiometric ages of basalts from these seamounts are not available. However, the magnetic anomaly pattern of Mt. Vavilov suggests that this volcano was built essentially during a reversed polarity epoch and that only the latest activity occurred within a normal polarity epoch. If the reversed epoch is the Matuyama, the volcano must be younger than 2.4 m.y.

\section{ALTERATION}

All the analyzed samples have a loss on ignition (L.O.I.) higher than $2.6 \%$ which is clearly related to hydration through alteration of the matrix. ${ }^{234} \mathrm{U} /{ }^{238} \mathrm{U}$ radioactive ratios have been found not to depart significantly from unity, suggesting that if the alteration process removed uranium, it took place more than 1 m.y. ago. Radioactive equilibrium prevails in the ${ }^{238} \mathrm{U}$ and ${ }^{232} \mathrm{Th}$ decay series.

It has been shown by several authors (see Hart et al., 1974; Winchester and Floyd, 1975) that sea-floor alteration of basalts mobilizes most major and some trace elements. Contrasting behaviors have been observed for some elements; it is, however, generally agreed that $\mathrm{TiO}_{2}, \mathrm{P}_{2} \mathrm{O}_{5}, \mathrm{Zr}, \mathrm{Hf}$, Th, and REE are largely unaffected by secondary alteration. These elements can therefore be utilized to recognize the petrogenetic affinity of altered basalts (Pearce and Cann, 1973).

In Hole $373 \mathrm{~A}$ basalts, no good correlation between abundances and water content (L.O.I.) has been found for any major (and trace) elements except $\mathrm{MgO}$, which increases regularly with increasing L.O.I. values ( $r$ $0.98)$. 


\section{PETROLOGY AND PETROGENETIC AFFINITY}

The normative mineralogy of the samples is represented in Figure 2d. Most of the samples are olivinetholeiites, showing differing contents of normative hypersthene up to very high values, possibly partly due to calcium loss during alteration. Sample 7-4, 130-135 $\mathrm{cm}$ has a low normative nepheline content. This last sample is, however, the most altered one as indicated by its high L.O.I. value (6.14\%).

The relative abundances of elements less sensitive to alteration confirm the tholeiitic character of Hole 373A basalts as shown by $\mathrm{P}_{2} \mathrm{O}_{5}-\mathrm{TiO}_{2}$ diagram (Figure 2a) and by $\mathrm{Zr} / \mathrm{P}_{2} \mathrm{O}_{5}$ ratio (Winchester and Floyd, 1976).

The distribution of major and trace elements (Figure 3 ) shows that the most basic lavas were recovered in Core 7 (differentiation index 21-27), whereas more evolved rocks were recovered in Core 4 (differentiation index 31) and Cores 2, 12, and outer barrel (differentiation index 36). The intermediate nature of these latter rocks is particularly emphasized by the lower contents of $\mathrm{Cr}$ and $\mathrm{Ni}$ and by the higher contents of
$\mathrm{Ta}, \mathrm{Zr}, \mathrm{Hf}$, and REE (Figure 4a). Th and $\mathrm{U}$ also increase except in Core 4 samples which display an unexplained abnormally low concentration. The refractory elements (e.g., Th, U, Hf, Zr, REE) are enriched in more evolved rocks (Core 12, outer barrel; Core 2) by a factor of 1.4-1.7 relative to the Core 7 rocks. For the hypothesis that these more evolved rocks were produced by crystal fractionation of a basaltic liquid represented by Core 7 samples, the enrichment factors imply that the separated solid phase constitutes some 25-50 percent by weight of the initial magma. However such a high fractionation is incompatible with the chemical differences observed between the two groups of rocks. Furthermore, the concentrations of other trace elements $(\mathrm{Ni}, \mathrm{Cr}, \mathrm{Ba}, \mathrm{Sr})$ are also inconsistent with such fractionation, even though $\mathrm{Ba}$ and $\mathrm{Sr}$ data are quite scattered, probably because of secondary alteration. The lack of linear correlation for pairs of hygromagmatophile elements (Treuil and Joron, 1975) also rules out crystal fractionation. Therefore, major and trace element distribution indicate that the two groups of rocks are not genetically linked by fractional crystal-
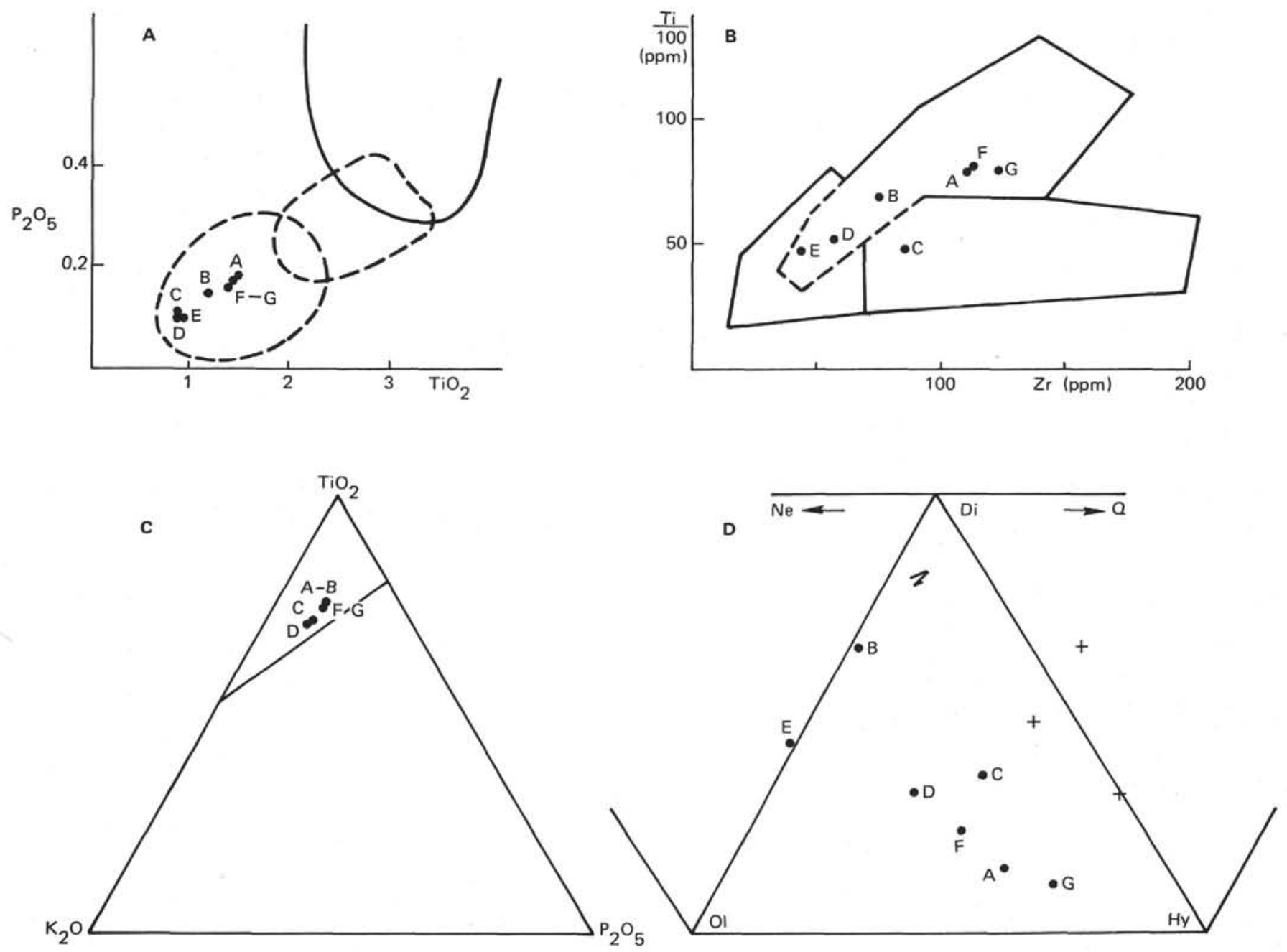

Figure 2. (a) P-Ti plot; (b) $\mathrm{Ti}-\mathrm{Zr}$ diagram; (c) $\mathrm{TiO}_{2}-\mathrm{P}_{2} \mathrm{O}_{5}-\mathrm{K}_{2} \mathrm{O}$ triangular diagram; (d) normative mineralogy in the basaltic tetrahedron. Dots: samples from this paper; Crosses: basalts from Seamounts of the Tyrrhenian Sea (from Del Monte, 1972). 

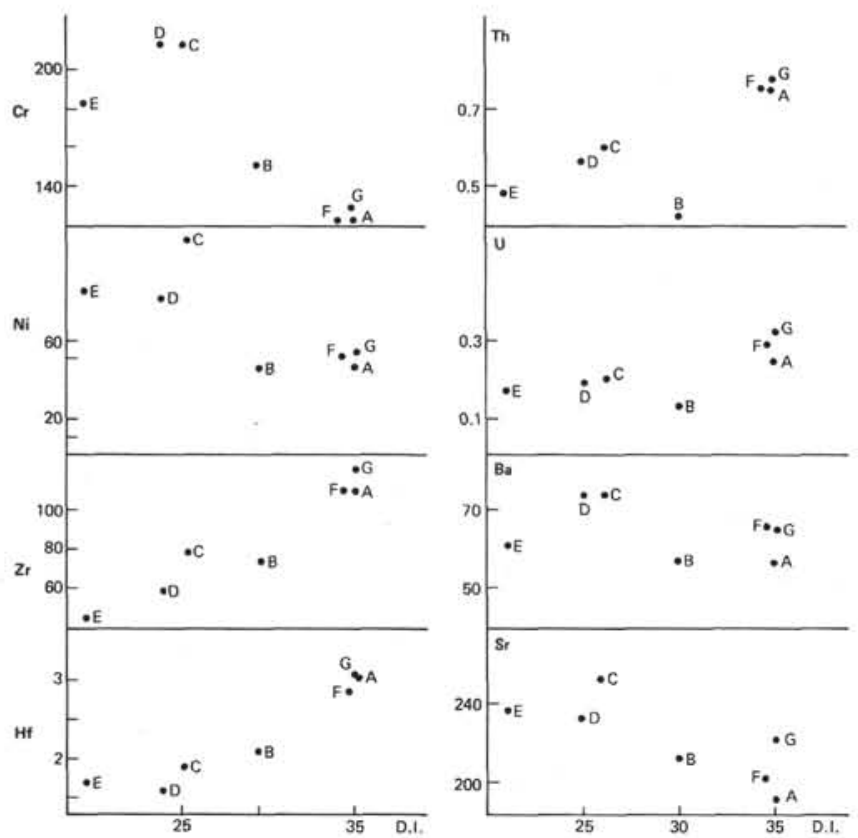

Figure 3. Trace elements $(\mathrm{ppm})$ plotted against differentiation index.

lization. The more evolved rocks were probably fractionated from a basaltic parent magma, but this magma has not been sampled in cores obtained from Hole 373A.

The relative abundances of $\mathrm{Ti}, \mathrm{P}, \mathrm{Zr}$, and $\mathrm{K}$ (Figure 2c) consistently point to an oceanic floor affinity of Hole $373 \mathrm{~A}$ tholeiites. This is also confirmed by REE data. Figure 4b shows actually that continental tholeiites have a pattern strongly enriched in light REE with an almost continuous decrease of concentration down to $\mathrm{Lu}$, whereas Tyrrhenian tholeiites display an almost flat pattern with a slight enrichment of light relative to intermediate REE and abundances within the general range of oceanic tholeiites. However, it is to be noted that REE pattern of analyzed samples differs from that typical of "normal" ridge light REE depleted tholeiites, whereas it is similar to the flat, or slightly light REE enriched, patterns of oceanic tholeiites occurring in spreading segments affected, according to Schilling (1975), by mantle plume activity (e.g., Mid-Atlantic Ridge in the proximity of Azores and Iceland). Tholeiitic basalts with similar REE pattern occur also in some spreading segments of Afar (Treuil and Joron, 1975), i.e., in a region affected by initial stages of continental break-up with a low rate of oceanic crustal accretion.

Geochemical data on theoleiites from marginal basins are available only for a few samples from the ocean basin behind the Mariana Island Arc (Hart et al., 1972; Ridley et al., 1974) and from the Lau Basin behind the Tonga Arc (Hawkins, 1976) (Figures 2a and $2 \mathrm{~b}$ ). These samples have a closer affinity to "normal" ridge tholeiites than Tyrrhenian samples (Figure 4b). However, it must be observed that some Mariana Trough basalts (Hart et al., 1972) display a REE pattern very similar to the Tyrrhenian tholeiites

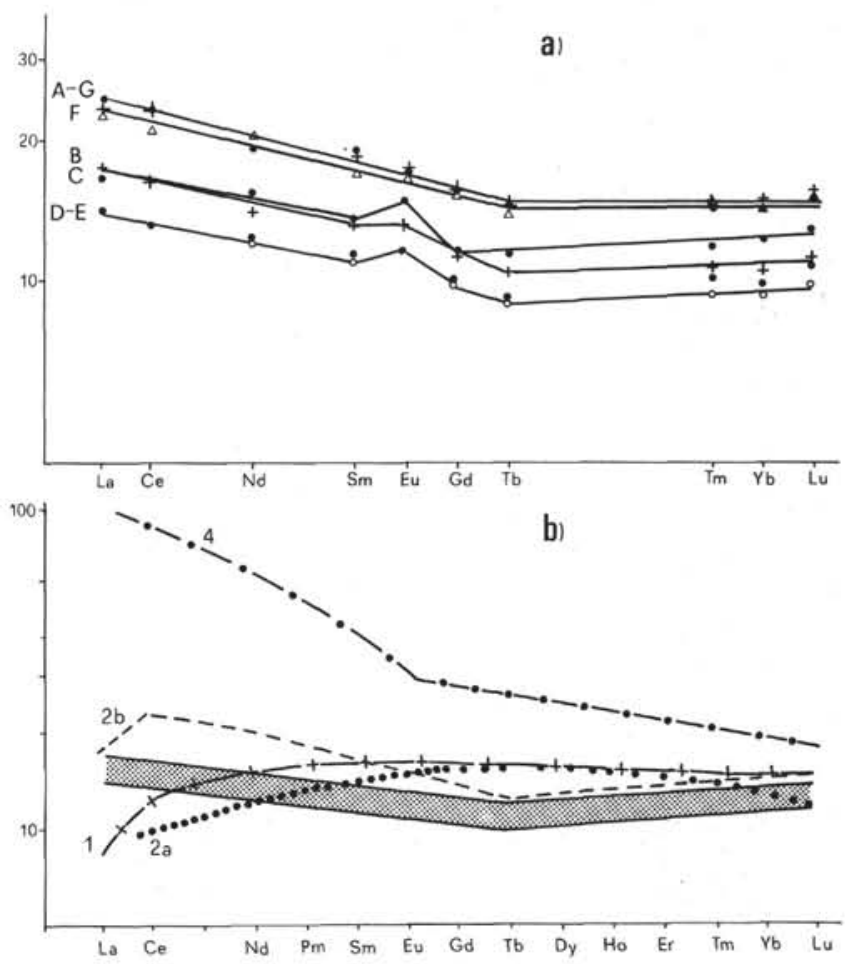

Figure 4. (a) chondrite normalized REE pattern for samples from Hole 373A; (b) chondrite normalized patterns of REE for continental tholeiites (4), (Schilling, 1971); normal ridge tholeiites (1) (Schilling, 1971); tholeiites from Tyrrhenian Abyssal Plain (only the less evolved rocks; shaded area).

except for an unusually sharp decrease in La relative to $\mathrm{Ce}$ and $\mathrm{Sm}$.

The $\mathrm{Sr}$ isotopic composition (see Table 4) is constant within analytical error for all samples (average 0.70304 ) and identical to that of tholeiites from Iceland and the northern part of the Reykjanes Ridge (O'Nions and Pankhurst, 1974; Hart el al., 1973) and not significantly higher than Mariana Trough basalts (avg. ${ }^{87} \mathrm{Sr} /{ }^{86} \mathrm{Sr}=0.7029$; Hart el al., 1972) or normal ridge segments (generally about 0.7030 ). These data rule out any possibility of contamination by continental crust for Tyrrhenian basalts.

The oceanic character of Tyrrhenian tholeiites lends strong support to the view that the Tyrrhenian Abyssal Plain is a back-arc marginal basin floored by new oceanic crust, rather than foundered continental crust.

\section{SUMMARY AND CONCLUSIONS}

Although all basalts from Hole 373A are affected by sea-water alteration, reliable age and petrochemical data have been obtained. Geochemical data consistently indicate that Tyrrhenian Abyssal Plain Basalts are oceanic tholeites unaffected by contamination with continental crust. The occurrence in the Tyrrhenian Abysal Plain of rocks with these geochemical characteristics has important implications.

This basin cannot be a portion of foundered continental crust partly "oceanized" by injection of hybrid- 
ized magmas. The most convincing structural model is, therefore, that of a back-arc basin formed by spreading. The 7.5 (3) m.y. age for the oldest recovered basalts obviously implies that oceanic crust formation was already active during Messinian times. This means that subsidence related to continental break-up and consequent establishment of the back-arc basin occurred in pre-Messinian time, in agreement with data from Leg 13, Site 132 (Ryan et al., 1973).

The rate of oceanic crust accretion inferred by $\mathrm{K} / \mathrm{Ar}$ data suggests a low rate of spreading. This is also confirmed by the occurrence of evolved products probably formed by fractionation of basalts during their ascent to the Tyrrhenian seafloor.

The distribution of large ion lithophile elements, as well as the $\mathrm{Sr}$ isotopic composition, suggest that the mantle source which fed these basalts had not been depleted in these elements by previous extraction of magma. These rocks show a close similarity to tholeiites occurring near supposed centers of deep mantle plume activity. However the occurrence of a subducting lithospheric slab which would tend to obstruct flow of material from deep in the mantle as well as the topography of the Tyrrhenian Abyssal Plain suggest that the Tyrrhenian tholeiites are unlikely to be related to plume activity.

\section{ACKNOWLEDGMENTS}

We are grateful to S. Moorbath for reviewing and to E. Bonatti for critically reading this paper.

\section{REFERENCES}

Barberi, F., Gasparini, P., Innocenti, F., and Villari, L., 1973. Volcanism of the southern Tyrrhenian Sea and its geodynamic implications: J. Geophys. Res, v. 78, p. 5221-5232.

Boccaletti, M. and Guzaaone, C., 1972. Gli archi appenninici, il Mar Ligure ed il Tirreno nel quadro della tettonica dei bacini retro-arco: Mem. Soc. Geol. Italy, v. 11, p. 201-216.

Capaldi, G., Cortini, M., Gasparini, P., and Pece, R., 1976. Short lived radioactive disequilibria in freshly erupted volcanic rocks and their implications for the genesis of magmas: J. Geophys. Res., v. 81, p. 86-96.

Chaya, B., Jaffrezig, H., Joron, J.L., 1973. Analyse par activation dans les neutrons épithermiques. Application à la détermination d'eléments dans les roches: Compt. Rend. Acad. Sci., Paris, p. 277.

Cioni, R., Innocenti, F., and Mazzuoli, R., 1971. Chemical analyses and some trace element data on standard silicate rocks: Chem. Geol., v. 7, p. 19-23.

Del Monte, N., 1972. Vulcenesimo del Mar Tizzeno: Nota preliminare sui vulcani Mazzili e Pelinuro: Giorn. Geol., v. 38 , p. 231-252.

Funkhouser, J. G., Fisher, R. L., and Bonatti, E., 1968. Excess argon in deep-sea rocks: Earth Planet. Sci. Lett. v., 5, p. 95-100.

Hart, S. R., Glassley, W. E., and Karig, D. E., 1972. Basalts and sea floor spreading behind the Mariana Island Arc: Earth Planet. Sci. Lett., v. 15, p. 12-18.
Hart, S. R., Schilling, J. G., and Powell, J. L., 1973. Basalts from Iceland and along Reykjanes Ridge: Sr-isotope geochemistry: Nature Phys. Sci., v. 246, p. 104-107.

Hart, S. R., Erlank, A. J., and Kable, E. J. D., 1974. Sea floor basalt alteration: some chemical and $\mathrm{Sr}$ isotopic effects: Contr. Mineral. Petrol., v. 44, p. 219-230.

Hayatsu, A., and Carmichael, C.M., 1970. K/Ar isochron method and initial argon ratios: Earth Planet. Sci. Lett., v. 8, p. 71-76.

Hawkins, J. W., 1976. Petrology and geochemistry of basaltic rocks of the Lau Basin: Earth Planet. Sci. Lett., v. 28, p. 283-297.

Heezen, B. C., Cray, C., Segre, A. G., and Zarudski, E. F. K., 1971. Evidence of foundered continental crust beneath the central Tyrrhenian Sea: Nature, v. 229, p. 327-239.

McDougall, J., Polack, H. A., and Stipp, J. J., 1969. Excess radiogenic Argon in subaerial basalts from the Auckland volcanic field, New Zealand: Geochim. Cosmochim. Acta, v. 33 , p. $1485-1520$.

O'Nions, R. K. and Pankhurst, R. J., 1974. Petrogenetic significance of isotopic and trace element variations in volcanic rocks from the Mid-Atlantic: J. Petrol., v. 15, p. 603-634.

Pearce, J. A. and Cann, J. R., 1973. Tectonic setting of basic volcanic rocks determined using trace element analyses: Earth Planet. Sci. Lett., v. 19, p. 290-300.

Ridley, W. I., Rhodes, J. M., Reid, A. M., Jakes, P., Shih, C., and Bass, M.N., 1974. Basalts from Leg 6 of the DeepSea Drilling Project: J. Petrol., v. 15, p. 140-159.

Ryan, W. B. .F., Hsü, H. J., et al., 1973. Initial Reports of the Deep Sea Drilling Project, Volume 8: Washington (U.S. Government Printing Office).

Schilling, J.G., 1971. Sea-floor evolution: rare earth evidence: Phil. Trans. Roy. Soc. London, A, v. 268, p. 663-706.

1975. Rare earth variations across "normal segment" of the Reykjanes Ridge, $60-53^{\circ} \mathrm{N}$, Mid-Atlantic Ridge, $29^{\circ} \mathrm{S}$, and East Pacific Rise, $2^{\circ}-19^{\circ} \mathrm{S}$, and evidence of the composition of the underlying low-velocity layer: J. Geophys. Res., v. 80, p. 1459-1473.

Selli, R. and Fabbri, A., 1971. Tyrrhenian: a Pliocenic deep sea: Atti Acad. Naz. Lincei, Cl. Sci. Fis. Mat. Natur., v. 8, p. 104-116.

Treuil, M. and Joron, J.L., 1975. Utilisation des elements hygromagmatophiles pour la semplification de la modalisation quantitative des processus magmatiques: Exemple de l'Afar et de la dorsale medio Atlantique: Soc. It. Mineral. et Petrol., v. 31, p. 125-174.

Treuil, M., Jaffrezic, H., Deschamps, N., Derre, C., Guichard, F., Joron, J. L., Pelletier, B., Novotny, S., and Courtois, C. 1973. Analyse des lanthanides du hafnium, du scandium, du chrome, du manganèse, du cobalt, du cuivre et du zinc dans les minéraux par activation neutronique: J. Radioanal. Chem., v. 18, p. 55-68.

Van Bemmelen, R.W., 1969. Origin of western Mediterranean Sea: Verh. Kon. Ned. Geol. Mijnbmouw. Genoot. Geol. Ser., v. 26, p. 13-52.

Winchester, J.A. and Floyd, P.A., 1975. Geochemical magma type discrimination: application to altered and metamorphosed basic igneous rocks: Earth Planet. Sci. Lett., v. 28, p. 459-469. 